\title{
A Study of the Evaluation of the Pecan Drought Resistance of Grafted 'Pawnee' Trees From Different Seedling Rootstocks
}

\author{
Fan Cao and Yunchu Wei \\ Co-Innovation Center for Sustainable Forestry in Southern China; College of \\ Forestry, Nanjing Forestry University, Nanjing 210037, China
}

\author{
Xinwang Wang \\ USDA-ARS Pecan Breeding and Germplasm Repository, 10200 FM 50, \\ Somerville, TX 77879 \\ Yongrong Li \\ Nanjing Green Universe Pecan Science \& Technology Co., Ltd., Nanjing \\ 210037, China
}

\section{Fangren Peng}

Co-Innovation Center for Sustainable Forestry in Southern China; College of Forestry, Nanjing Forestry University, Nanjing 210037, China

Additional index words. Carya illinoinensis, drought stress, PV curve, rootstock selection

\begin{abstract}
To describe the influence of different pecan seedling rootstocks on drought stress resistance, 12 rootstocks of '87MX1-2.2', '87MX5-1.7', 'Elliott', 'Frutoso', 'Giles', 'Major', 'Moore', 'Peruque', 'Posey', 'Riverside', 'San Felipe', and 'VC1-68' were selected as rootstock treatments for grafting. In addition, the experimental materials for the grafted young 'Pawnee' tree treatments included the pressure-volume technique (PV technique) and cutting shoot transpiration methods to plot the PV and the cutting shoot transpiration curves, and the parameters calculated from the two curves were used to analyze the data produced by the subordinate function and cluster dendrogram methods. The results revealed that the different seedling rootstock treatments influenced the 'Pawnee' grafted trees to varying degrees on aspects of drought resistance, the ability to save water, the modulation of osmosis, and the sensitivity of the stomatal response. The order of drought tolerance for these different pecan seedling rootstock treatments from high to low was as follows: 'Posey', 'Peruque', 'Riverside', '87MX5-1.7', 'VC1-68', 'Elliott', '87MX1-2.2', 'San Felipe', 'Moore', 'Major', 'Giles', and 'Frutoso'.
\end{abstract}

Pecan [Carya illinoinensis (Wangenh.) K. Koch], a member of the hickory (Carya spp., Juglandaceae) genus, is native to North America. As a long-lived perennial tree crop, it has evolved from being a relatively minor wild component of riparian ecosystems to a significant silvicultural and horticultural crop (Wood et al., 1990), and it has been one of the most significant fruit crops in the United States (Wood, 2001). The large amount of benefits of pecans includes the rich taste of the kernel; a lack of bitterness; and a high content of fatty acids, proteins, phospholipids, and vitamins (Huang et al., 2019). These benefits have resulted in the provision

\footnotetext{
Received for publication 23 July 2019. Accepted for publication 19 Sept. 2019

This project was supported by Jiangsu Forestry Science and Technology Innovation and Promotion Project [LYKJ(2018)05-1] and Priority Academic Program Development of Jiangsu Higher Education Institutions (PAPD).

F.P. is the corresponding author. E-mail: frpeng@ njfu.edu.cn.
}

of highly significant contributions to applications in the food industry, including baking; producing confections, ice cream, and gift packs; retailing; wholesaling; and serving various food service outlets. In addition to these features, it has the additional economic benefits of its uses in horticulture, the manufacture of wood, and as a source for the extraction of oil (Xue et al., 2018). As a tall arbor tree, the pecan tree also has significant ecological benefits for agroforestry systems (Guo et al., 2018a, 2018b). With the gradual realization of the potential value of the pecan, global demands for the nut have continued to increase annually. Countries outside the native range of the tree, including China, South Africa, Australia, Uruguay, Argentina, and Brazil, are now producing pecans, and their production is expected to increase over the next 30 years (Casales et al., 2018; Lazarotto et al., 2014; Wakeling et al., 2001; Zhang et al., 2015b). Therefore, further study on pecan propagation is merited.

To date, compared with other pecan cloning propagation techniques that include cut- ting and tissue culture, grafting is the most traditional and effective method to produce pecan cultivar trees (Zhang et al., 2015a). The growth of the grafted pecan tree is affected by its complex genetic system, which is determined by both the rootstock and scion. Although growers are still finding a more efficient propagation for the scion cultivar, instead of breeding or searching rootstocks, a better understanding of the impact of rootstocks on the growth of scion is necessary to the specific production goals. It is known that appropriate rootstocks not only provide scion resistance to environmental stresses but also increase growth vigor to reduce both the vegetative and reproductive times of the scion, therefore increasing market competition. In addition, a good rootstock can reduce orchard management costs and indirectly increase profits for the pecan growers.

A better understanding of the adaptation of the rootstocks to the specific constraints in certain orchards provides useful guides to monitor the performance of pecan trees to maximally increase the production of the orchard. Therefore, knowing the adaptation of different rootstocks to different environments becomes important for pecan breeders and growers, particularly for a long-term goal of the U.S. pecan breeding program.

A seedstock is the source of the seed planted to produce seedling rootstocks. Seedstock selections made by nurserymen have an apparent geographic distribution. The most critical limitation for a rootstock is its adaptation to the climate of the region. For example, the 'Moore' seedling was used as a rootstock in the eastern United States. It is a seedling selection from Florida, originating in Jefferson County near the town of Waukeenah, FL (Hammar and Hunter, 1949). Although pecans in Florida were introduced, the source of the seed that produced 'Moore' is unknown. 'Moore' carries the maternal haplotype most common in northern pecans that is also found in populations from Mexico and Texas (Grauke, 2010; Grauke et al., 2011). 'Moore' is a sib of the pecan cultivar Waukeenah, which is also used as a rootstock in the southeastern United States (Grauke and O'Barr, 1996; Grauke and Pratt, 1992). These trees are protandrous, with early pollen and midseason pistillate receptivity. 'Moore' was the most productive rootstock used in a test in Shreveport, LA, in the 1930s (Sitton and Dodge, 1938) and has produced the largest seedlings in tests that began in the 1980s (Carpenter et al., 1979). This rootstock produces vigorous and uniform seedlings that have some resistance to scab disease. Another example is ' $\mathrm{VC} 1-68$ ', a rootstock selection that originated near Phoenix, AZ, and is used as a popular rootstock in the western United States, particularly California (Grauke, 2010). The tree is protandrous with early pollen shed and midseason pistillate receptivity. The nuts are very large (41 nuts per pound) but are thick-shelled, resulting in a low kernel percentage $(\approx 43 \%)$. The nuts germinate well, and the seedlings are uniform and vigorous, with excellent lateral root 
formation. The parent 'Cape Fear' is very susceptible to scab, but observations of the progeny suggest that they do not have this problem. Its freeze susceptibility may limit the use of this rootstock to the southern part of the southeastern and southwestern United States. However, different rootstocks have one or more contributions to tree growth, nut production, and/or nut quality, including consistent high quality, precociousness, early harvest, a high yield, a low degree of alternate bearing, late budbreak, scab resistance, and aphid tolerance for the mature pecan tree. Thus, understanding the impacts of various rootstocks on scion growth and nut production increases the interests of the breeders and growers. For example, physiological stress resistance is one of the major goals of rootstock breeding.

This study describes the drought stress resistance of the grafted young 'Pawnee' trees onto 12 different pecan seedling rootstocks. The objectives of this study were as follows: 1) to determine the effects of different rootstocks on the drought tolerance of the scion ('Pawnee') to provide guidance for the selection of the most drought-tolerant pecan rootstock, which would also support further pecan cultivation research in arid and semiarid areas; and 2) to analyze the differential water parameters of the same grafted 'Pawnee' scions to understand the interaction between the rootstock and scion, thus, providing a foundation for functional genomics research in pecan.

\section{Materials and Methods}

Plant materials. The seeds of 12 pecan trees were harvested in the Pecan Repository (College Station and Brownwood, TX) in 2008. The 12 trees were '87MX1-2.2', '87MX5-1.7', 'Elliott', 'Frutoso', 'Giles', 'Major', 'Moore', 'Peruque', 'Posey', 'Riverside', 'San Felipe', and 'VC1-68', which were derived from trees in the United States or Mexico. In 2010, dormant 1-year-old stick woods of 'Pawnee' were bud grafted on these seedlings of 12 treatments in a greenhouse. Twenty grafted trees of each rootstock, a total of 240 grafted trees, were planted in four blocks in 2012. That is to say, there were 60 trees, five of 12 rootstock treatments, in each block, which included four rows, 15 grafted trees per row, that were arranged in a completely randomized design of a test orchard.

$P V$ technique. For this study, one block of this rootstock test orchard was randomly selected for sampling. In July 2018, 10 straight normal healthy shoots of one seedling rootstock treatment with leaflets were randomly collected from the middle canopy of grafted 'Pawnee' trees. For one seedling rootstock treatment group, five of the 10 selected shoots were cut $\approx 10 \mathrm{~cm}$ long without any leaflets and placed in double-distilled water in a container, placed in a dark and humid room overnight for the PV technique test. All the saturated shoots were weighed individually as the fresh weight. The shoot was immediately inserted into a pressure chamber. After the entire pressure pump was loaded, the air pressure was added using the Scholand-Hammel method at room temperature (Scholander et al., 1965). The sap was collected for weighing using a pipetting gun. The PV was recorded during the whole process. A complete PV curve was drawn with the accumulation of the pressured sap weight as the abscissa and the reciprocal value of the added pressure as the ordinate. The dry weight of the same shoot was measured after drying in an oven at $80{ }^{\circ} \mathrm{C}$ for $48 \mathrm{~h}$. The relative water content was defined as the following parameters: the osmotic potential at plasmolysis $\left(\Psi_{\mathrm{w}}^{\text {tlp }}\right)$ (the inverse of the point at which the fitting line intersected the y-axis), osmotic potential at the saturated water content $\left(\Psi_{\mathrm{w}}^{\text {sat }}\right)$ (the inverse of the ordinate at which the fitting curve intersected the fitting line), saturated water content of the shoot (Vo) (the point at which the line intersected the $\mathrm{x}$-axis) (Fig. 1), the total content of the water removed under stress at plasmolysis ( $\mathrm{Ve})$, and the total water content of the saturated shoot $(\mathrm{Vt})$. The relative water content at the turgor loss point $\left(\mathrm{RWC}^{\mathrm{tlp}}\right)$, relative osmosis water content at the turgor loss point (ROWC $\left.{ }^{\mathrm{tlp}}\right)$, and the ratio of bound water to free water $\left(\mathrm{V}_{\mathrm{a}} / \mathrm{V}_{\mathrm{p}}\right)$ were calculated using the following formulae: $\mathrm{RWC}^{\text {tlp }}=(\mathrm{Vt}-\mathrm{Ve}) / \mathrm{Vt}$; ROWC $\mathrm{R}^{\mathrm{tlp}}=\left(\mathrm{Vo}_{-}\right.$ $\mathrm{Ve}) / \mathrm{Vo}$; and $\mathrm{V}_{\mathrm{a}} / \mathrm{V}_{\mathrm{p}}=(\mathrm{Vt}-\mathrm{Vo}) / \mathrm{Vt}$. The bulk elastic modulus $(\varepsilon)$, which reflects the rate of the cellular volume varying with turgor pressure changing, was calculated as $\varepsilon=\mathrm{V}$ $(\mathrm{dP} / \mathrm{dV})$, where $\mathrm{V}$ is the volume of free water, and $\mathrm{P}$ is pressure potential. The most bulk elastic modulus $\left(\varepsilon^{\max }\right)$, which represented the physical property of the cell wall, was also chosen and measured as one parameter for the evaluation of drought resistance.

Cutting shoot transpiration measurement. In the cutting shoot transpiration measurement, the other five shoots were also cut into pieces $\approx 10 \mathrm{~cm}$ long but with six to eight pieces of leaflets and placed in a shaded room at room temperature for the 24-h water absorption treatment. After the saturated water absorption, Vaseline was applied to the incisions of the shoots to prevent water loss. The weight of the shoots was measured per hour from 10:00 AM to 7:00 PM under strong light $(>10,000$ Lux $)$. The whole leaf

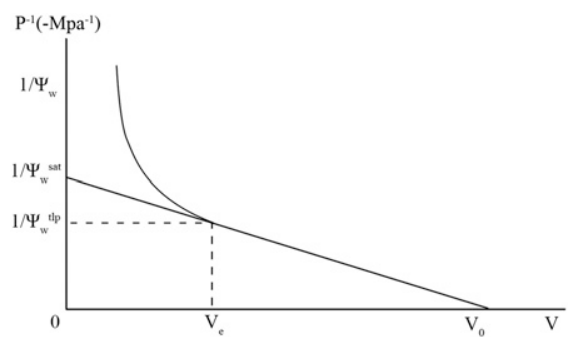

Fig. 1. Pressure-volume technique curve. $\mathrm{Ve}=$ the total content of the water removed under stress at plasmolysis; $\mathrm{Vo}=$ saturated water content of the shoot; $\Psi_{\mathrm{w}}=$ water potential; $\Psi_{\mathrm{w}}{ }^{\text {sat }}=\psi_{\mathrm{S}}$ at the saturated water content; $\Psi_{\mathrm{w}}{ }^{\text {tlp }}=$ the $\psi_{\mathrm{S}}$ at plasmolysis. area of each treatment was measured using a laser leaf planimeter (CID-203; CID BioScience, Inc., Camas, WA). The cutting shoot transpiration curve was drawn on the basis of the time-varying decremental mass (Fig. 2). Two straight regression lines were calculated from the upper and lower parts of the cutting shoot transpiration curve, respectively. The slope value of the regression line at the top of the curve represented the sum of the maximum stomatal transpiration rate and the maximum cuticular transpiration rate under the conditions of full stomatal opening shortly after the beginning of the measurement. The slope value of the regression line at the bottom of the curve represented the maximum transpiration rate of the stratum corneum when the stomata were completely closed. Thus, the stomatal transpiration rate (STR), cuticular transpiration rate (CTR), and maximum stomatal transpiration rate $\left(\mathrm{STR}_{\max }\right)$ were obtained. In addition, the intersection point of the curve and the upper straight regression line presented the beginning point of the opening of the stomata, and the intersection point of the curve and the lower part of the regression line were considered to be the complete closing point of the stomata. Therefore, $\mathrm{T}_{\mathrm{S}}$ (the processing time when the stomata began to close) and $\mathrm{T}_{\mathrm{C}}$ (the processing time of the complete closure of the stomata) were calculated, respectively. In addition, the distance between the two intersection points was called the $D$ value, which reflected the sensitivity in the stomatal closing process. The lower the $D$ value, the faster the stomata closed.

Statistical analysis. The PV curve and cutting shoot transpiration curve of each rootstock treatment was drawn using SigmaPlot 12.5 (Systat Software, Inc., Chicago, IL) (Li et al., 2004). The data were analyzed using SPSS 25.0 software (SPSS, Inc., Chicago, IL), and multiple comparisons were performed using the Duncan method $(P<$ 0.05 ). The subordinate function method was used to comprehensively evaluate the comprehensive indices of the different rootstock treatments. If the parameter measured is positively correlated with the comprehensive index of the comparison of the different rootstock treatments, the formula is as follows: $R\left(X_{i}\right)=\left(X_{i}-X_{\min }\right) /\left(X_{\max }-X_{\min }\right)$. If the parameter measured is negatively correlated with the comprehensive index, the formula is

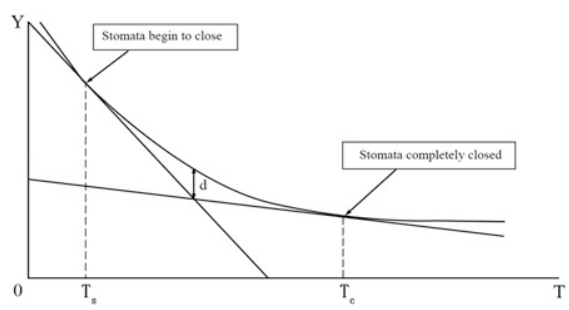

Fig. 2. Cutting shoot transpiration curve. $\mathrm{T}_{\mathrm{S}}=$ the processing time when the stomata began to close; $\mathrm{T}_{\mathrm{C}}=$ the processing time of the complete closure of the stomata; $\mathrm{d}=D$ value. 
as follows: $R\left(X_{i}\right)=1-\left(X_{i}-X_{\min }\right) /\left(X_{\max }-\right.$ $\left.X_{\min }\right) i=1,2,3, \ldots \mathrm{n}$, where $R\left(X_{i}\right)$ is the subordinated value of each physiological parameter, and $X_{\min }$ and $X_{\max }$ are the minimum and maximum values of each parameter determined, respectively. The average of $R\left(X_{i}\right)$ of the different cultivars of pecans was calculated, with the higher average indicating stronger tolerance. The dendrogram trees were drawn using SPSS 25.0 on the basis of the comparison of the comprehensive indices of the different pecan rootstock treatments.

\section{Results}

The maximum osmotic potential $\left(\Psi_{\mathrm{w}}^{\text {sat }}\right)$ of the grafted 'Pawnee' tree shoots from different rootstocks at their saturation point and water potential at incipient plasmolysis $\left(\Psi_{\mathrm{w}}{ }^{\text {tlp }}\right)$ is shown in Fig. 3. The 'Peruque' and 'Posey' rootstocks showed a significant difference in their $\Psi_{\mathrm{w}}^{\text {sat }}$. In addition, the higher $\Psi_{\mathrm{w}}{ }^{\text {tlp }}$ absolute value indicated that the plasmolysis of the rootstock treatment had more difficulty occurring in the soil with low water potential. In the test, the rootstock treatments of '87MX1-2.2', '87MX5-1.7', 'Elliott', 'Peruque', 'Posey', and 'San Felipe' had a high level of the $\Psi_{\mathrm{w}}^{\text {tlp }}$ absolute value.

With the exception of the 'Peruque' seedling treatment, the other rootstock treatments showed no difference in the $\mathrm{RWC}^{\text {tlp }}$, which indicated that the external water pressure was similar when the plasma wall separation occurred. ROWC ${ }^{\text {tlp }}$ is an important index of drought tolerance (Tyree and Hammel,
1972). Generally, a lower ROWC ${ }^{\text {tlp }}$ value indicates that the plasmolysis of the plant cell occurs at a lower osmosis water content, so that it can reflect the tolerance of the plant cell to dehydration to some degree. In this PV technique test, shown in Table 1, the ROWC $^{\text {tlp }}$ value of the 'Peruque' treatment was the lowest, which indicated that it had a strong capability to endure dehydration. In contrast, the 'Frutoso' and 'Major' treatments had a high ROWC ${ }^{\text {tlp }}$ value.

There were three factors that contributed to the osmotic regulation of the mature tree: the reduction in the water content of the plant cell, the decrease of the cell volume, and the increase of solutes in the cell (Wilson et al., 1980). However, the change in $\mathrm{V}_{\mathrm{a}} / \mathrm{V}_{\mathrm{p}}$ can noticeably reflect the value of TW/TD and the solute accumulation in the cell, and it is also an important parameter to estimate the degree of plant stress resistance. In the experiment, the highest $\mathrm{V}_{\mathrm{a}} / \mathrm{V}_{\mathrm{p}}$ value was that of the '87MX5-1.7' treatment, and the lowest was the 'Frutoso' treatment.

The bulk elastic modulus $(\varepsilon)$ of a cell reflects the rate at which the turgor pressure varies with volume. Because $\varepsilon$ is not constant, the most bulk elastic modulus $\left(\varepsilon^{\max }\right)$ is generally used to represent one physical property of the cell wall. The higher $\varepsilon^{\max }$ value represents the harder and less elastic cell wall. With the decrease in the water content and water potential, the highly elastic tissue is better able to maintain turgor than the tissue with a low degree of elasticity. Therefore, $\varepsilon$ plays an important role in evaluating the drought tolerance of the trees

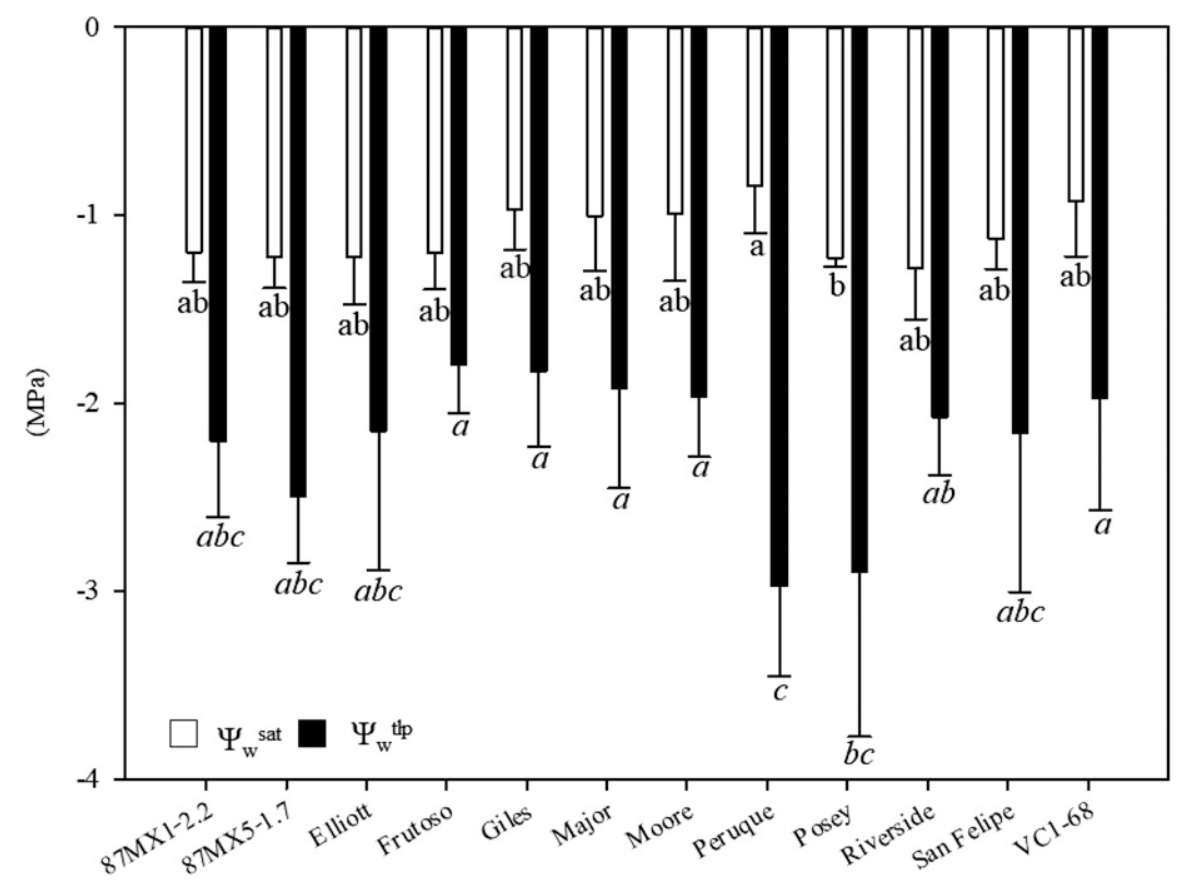

Fig. 3. Maximum $\psi_{\mathrm{S}}$ of grafted 'Pawnee' tree shoots from different pecan seedling rootstocks at the saturation point and water potential at incipient plasmolysis. For $\Psi_{\mathrm{w}}{ }^{\text {sat }}$, the same lowercase letters indicate no significant difference $(P>0.05)$, whereas different lowercase letters indicated a significant difference $(P<0.05)$. For $\Psi_{\mathrm{w}}^{\text {tlp }}$, the same lowercase and inclined letters indicated no significant difference $(P>0.05)$, whereas different lowercase and inclined letters indicated a significant difference $(P<0.05)$

because the tissue elasticity can determine the change in the pressure potential. Table 1 shows that the $\varepsilon^{\max }$ of the different seedling rootstock treatments exhibited significant differences. Among them, the 'Riverside' treatment had the highest $\varepsilon^{\max }$ value (8.25), indicating that it was the most elastic, which helped the ability of the cytoplasm to tolerate dehydration. In addition, the 'Frutoso' (7.05), 'Posey' (7.17), and 'San Felipe' (7.14) seedling treatments also had high $\varepsilon^{\max }$ values. In contrast, the 'Peruque' treatment with the lowest $\varepsilon^{\max }$ value (3.01) was less elastic.

During the cutting shoot transpiration test, when the stomata began to close, the relative rank for the water content of the different rootstock treatments was 'San Felipe' (93.69\%), '87MX5-1.7' (93.5\%), 'Major' (93.44\%), 'Giles' (93.15\%), 'Elliott' (93.06\%), '87MX1-2.2' (92.4\%), 'Frutoso' (92.29\%), 'Moore' (92.13\%), 'Peruque' (89.6\%), 'VC1-68' (89.28\%), 'Posey' $(88.3 \%)$, and 'Riverside' $(87.91 \%)$, respectively. In addition, when the stomata completely closed, the relative rank of the water content of the different rootstock treatments was 'Elliott' (82.31\%), 'Giles' (81.92\%), '87MX1-2.2' (81.71\%), '87MX51.7 ' (80.69\%), 'Major' (80.36\%), 'Peruque' (79.95\%), 'VC1-68' (79.82\%), 'Posey' (79.57\%), 'San Felipe' (79.31\%), 'Riverside' (78.99\%), 'Frutoso' (78.85\%), and 'Moore' $(78.12 \%)$, respectively (Fig. 4). Measurements of the loss of the relative water content from the stomata that were beginning to close to the stomata that had completely closed indicated that the 'Major' and 'San Felipe' treatments differed the most significantly, which indicated that the sensitivity of their stomata to closure was less than that of the other rootstock treatments.

Based on the cutting shoot transpiration curve (Fig. 2), $T_{S}$ and $T_{C}$ could be calculated from the intersection points of the fitting curve and the fitting line. For $\mathrm{T}_{\mathrm{S}}$, none of the rootstock treatments showed a significant difference, which indicated that they had a similar initial reaction to the external environmental light stimuli. An examination of $\mathrm{T}_{\mathrm{C}}$ indicated that the rootstock treatment of '87MX5-1.7' and 'San Felipe' took longer until the stomata completely closed, which resulted in a greater degree of water loss.

Table 2 reveals that there was no significant difference in the transpiration rate of the stomata of the different rootstock treatments. Only the 'San Felipe' treatment had a larger difference than 'Elliott' in the CTR. It could be hypothesized that the rootstock of the different rootstocks had less of an influence on the transpiration rate of the 'Pawnee' scion, which merits additional research.

The $D$ value was also a parameter that reflected the degree of sensitivity in the stomatal closing process. In the experiment on the transpiration of the pecan cutting shoots, only the 'San Felipe' treatment expressed a larger difference than that of the 'Posey' treatment. Combined with the results of the loss of the relative water content, the $\mathrm{T}_{\mathrm{C}}$, and CTR, the 'San Felipe' 
Table 1. Effects of the PV technique on several parameters in grafted 'Pawnee' tree shoots from different pecan seedling rootstocks.

\begin{tabular}{lccrr}
\hline Rootstock & \multicolumn{1}{c}{ RWC $C^{\text {tlp }}(\%)$} & \multicolumn{1}{c}{ ROWC ${ }^{\text {tlp }}(\%)$} & \multicolumn{1}{c}{$\mathrm{V}_{\mathrm{a}} / \mathrm{V}_{\mathrm{p}}$} & \multicolumn{1}{c}{$\varepsilon^{\max }(\mathrm{MPa})$} \\
\hline 87MX1-2.2 & $77.31 \mathrm{ab} \pm 9.72$ & $53.19 \mathrm{abc} \pm 10.07$ & $1.23 \mathrm{bcd} \pm 0.49$ & $6.29 \mathrm{abcd} \pm 1.69$ \\
87MX5-1.7 & $80.58 \mathrm{ab} \pm 10.88$ & $48.02 \mathrm{abc} \pm 12.92$ & $2.44 \mathrm{a} \pm 0.66$ & $5.08 \mathrm{abcd} \pm 1.96$ \\
Elliott & $85.87 \mathrm{a} \pm 4.25$ & $57.64 \mathrm{ab} \pm 15.00$ & $2.31 \mathrm{ab} \pm 1.52$ & $6.70 \mathrm{abc} \pm 1.69$ \\
Frutoso & $80.69 \mathrm{ab} \pm 4.74$ & $65.11 \mathrm{a} \pm 4.68$ & $0.89 \mathrm{~d} \pm 0.38$ & $7.05 \mathrm{abcd} \pm 1.66$ \\
Giles & $76.39 \mathrm{ab} \pm 14.63$ & $53.21 \mathrm{abc} \pm 14.21$ & $1.91 \mathrm{abcd} \pm 0.43$ & $4.80 \mathrm{de} \pm 1.05$ \\
Major & $78.25 \mathrm{ab} \pm 9.84$ & $65.18 \mathrm{a} \pm 6.38$ & $1.62 \mathrm{abcd} \pm 1.04$ & $5.01 \mathrm{cde} \pm 1.75$ \\
Moore & $78.17 \mathrm{ab} \pm 9.37$ & $53.62 \mathrm{abc} \pm 17.52$ & $1.13 \mathrm{~cd} \pm 0.36$ & $4.65 \mathrm{bcde} \pm 1.46$ \\
Peruque & $66.21 \mathrm{~b} \pm 7.35$ & $33.13 \mathrm{c} \pm 4.81$ & $1.22 \mathrm{bcd} \pm 0.57$ & $3.01 \mathrm{e} \pm 0.23$ \\
Posey & $77.14 \mathrm{ab} \pm 8.88$ & $37.75 \mathrm{bc} \pm 18.24$ & $1.88 \mathrm{abcd} \pm 0.72$ & $7.17 \mathrm{ab} \pm 0.93$ \\
Riverside & $83.03 \mathrm{a} \pm 4.29$ & $58.48 \mathrm{ab} \pm 11.69$ & $1.43 \mathrm{abcd} \pm 0.09$ & $8.25 \mathrm{a} \pm 1.35$ \\
San Felipe & $85.10 \mathrm{a} \pm 9.34$ & $53.99 \mathrm{abc} \pm 18.21$ & $2.27 \mathrm{abc} \pm 0.49$ & $7.14 \mathrm{abcd} \pm 3.07$ \\
VC1-68 & $77.91 \mathrm{ab} \pm 5.50$ & $44.69 \mathrm{abc} \pm 10.20$ & $1.58 \mathrm{abcd} \pm 0.50$ & $4.47 \mathrm{bcde} \pm 2.34$ \\
\hline
\end{tabular}

The same lowercase letters indicate no significant difference $(P>0.05)$, whereas different lowercase letters indicate a significant difference $(P<0.05) . \mathrm{RWC}^{\mathrm{tl} p}=$ relative water content at the turgor loss point; ROWC ${ }^{\text {tlp }}=$ relative osmosis water content at the turgor loss point; $\mathrm{V}_{\mathrm{a}} / \mathrm{V}_{\mathrm{p}}=$ ratio of bound water to free water; $\varepsilon^{\max }=$ most bulk elastic modulus.

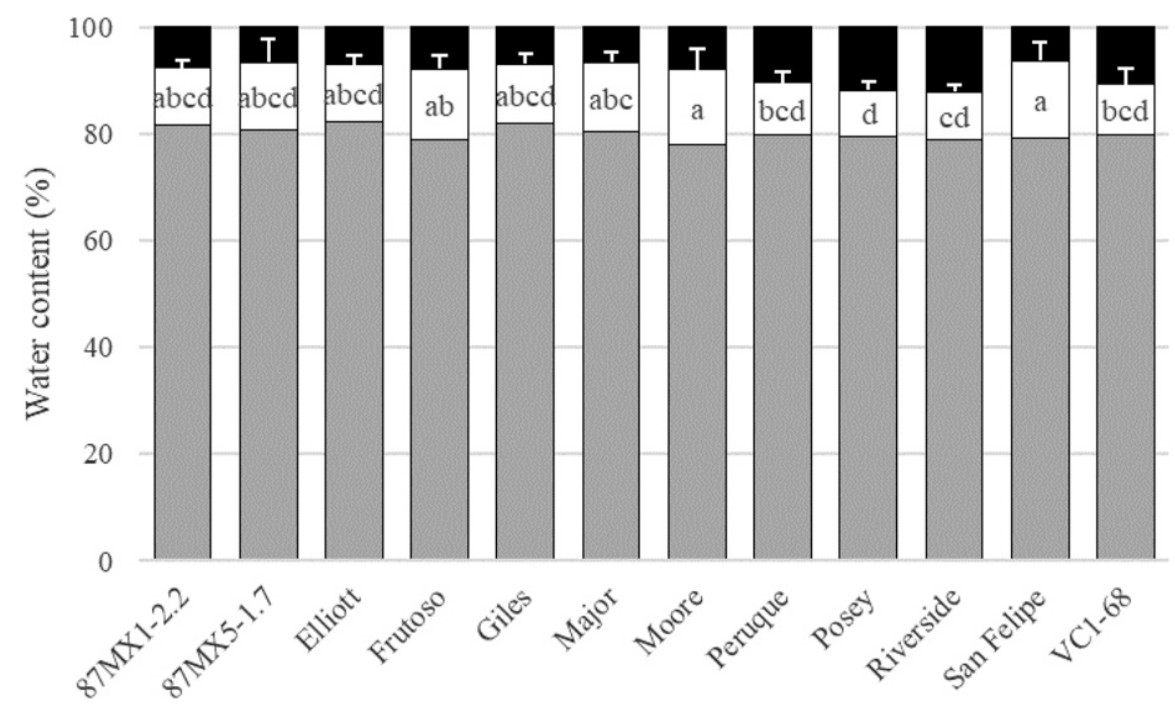

Fig. 4. Changes in the water content in the cut shoots of grafted 'Pawnee' tree from different pecan seedling rootstocks. The white part with lowercase letters presents the loss of water content from when the stomata begin to close to when the stomata have completely closed. The same lowercase letters indicate no significant difference $(P>0.05)$, whereas different lowercase letters indicate a significant difference $(P<0.05)$.

rootstock treatment showed the most differential reaction in the cutting shoot transpiration test.

To comprehensively and objectively evaluate the effects of the 12 seedling rootstock treatments on the characteristics of drought resistance, the ability to save water, the modulation of osmosis, and the sensitivity of the response of the stomata, the subordinate function method was used. This method summed the membership function values of each index of the different seedling rootstock treatments and calculated their average value. Higher average values indicate that the seedling rootstock treatment performed more strongly (Table 3 ). A cluster analysis was conducted based on the membership function values of the four comprehensive indices of the 12 seedling rootstock treatments (Fig. 4).

To calculate the comprehensive index of drought resistance, the parameters of $\Psi_{\mathrm{w}}$ sat, $\Psi_{\mathrm{w}}^{\text {thp }},\left|\Psi_{\mathrm{w}}^{\text {sat }}-\Psi_{\mathrm{w}}^{\text {th }}\right|,\left|\Psi_{\mathrm{w}}^{\text {tlp }} \mathrm{X} R \mathrm{RWC}^{\text {tp }}\right|, \mathrm{V}_{\mathrm{a}} / \mathrm{V}_{\mathrm{p}}$, $\varepsilon^{\max }$, the relative water content when the stomata began to close, the relative water content when the stomata completely closed, the loss of relative water content in the stomatal closing process and the $D$ value were selected. Among them, $\left|\Psi_{\mathrm{w}}^{\text {sat }}-\Psi_{\mathrm{w}}^{\text {tlp }}\right|, \mid \Psi_{\mathrm{w}}^{\text {tlp }}$ X RWC ${ }^{\text {tlp }} \mid$, $\mathrm{V}_{\mathrm{a}} / \mathrm{V}_{\mathrm{p}}$, and the relative water content when the stomata began to close were positively correlated with drought resistance, and the others were negatively correlated. The treatment rank of the comprehensive evaluated result $\left(\mathrm{R}_{1}\right.$ value) from high to low was 'Posey', 'Peruque', 'Riverside', '87MX5-1.7', 'VC1-68', 'Elliott', '87MX1-2.2', 'San Felipe', 'Moore', 'Major', 'Giles', and 'Frutoso', respectively (Table 3 ). The cluster analysis of the drought-tolerant ability (Fig. 5A) indicated that the 'Posey' treatment exhibited the highest degree of drought resistance. The different seedling rootstock treatments could be classified into two primary categories: drought tolerance and a relatively lower degree of drought tolerance.
The seedling rootstock treatments of the 'Peruque', 'Riverside', '87MX5-1.7', and 'VC1-68' treatments had the highest degree of drought tolerance. However, the 'Moore', 'Frutoso', 'Giles', and 'Major' treatments exhibited a relatively lower degree of drought tolerance.

The subordinate function method was also used to analyze the water-saving and retention ability. The method selected RWC ${ }^{\text {tlp }}$, $\mathrm{V}_{\mathrm{a}} / \mathrm{V}_{\mathrm{p}}, \varepsilon^{\max }$, the relative water content when the stomata completely closed, $D$ value, $\mathrm{T}_{\mathrm{S}}$, $\mathrm{T}_{\mathrm{C}}$, and the maximum transpiration rate as the indices for analysis. Among them, RWC ${ }^{\text {tlp }}, \mathrm{V}_{\mathrm{a}} / \mathrm{V}_{\mathrm{p}}$, and the relative water content when the stomata were completely closed were positively correlated with the watersaving ability, whereas the other indices were negatively correlated. The rootstock treatment rank of the comprehensive result evaluated $\left(\mathrm{R}_{2}\right.$ value) from high to low was 'Elliott', 'Posey', 'Riverside', '87MX1-2.2', 'VC1-68', 'Giles', '87MX5-1.7', 'Major', 'San Felipe', 'Peruque', 'Frutoso', and 'Moore', respectively (Table 3 ). The different rootstock treatments could be classified into two primary categories using cluster analysis, high and low water-saving, and retention ability (Fig. 5B). In the memberships of the high water-saving ability group, the 'Elliott' treatment was the most strongly expressed, and the ability of the '87MX5-1.7' treatment to save water was relatively lower than that of the other treatments of this group. In addition, in the other group, the 'Moore' treatment was the most poorly expressed.

The calculation of the comprehensive index of the osmotic regulating ability used $\Psi_{\mathrm{w}}{ }^{\text {sat }}, \Psi_{\mathrm{w}}{ }^{\text {tlp }}$, and $\left|\Psi_{\mathrm{w}}{ }^{\text {sat }}-\Psi_{\mathrm{w}}{ }^{\text {tlp }}\right|$. The former two were negatively correlated with the osmosis modulation, whereas $\left|\Psi_{\mathrm{w}}^{\text {sat }}-\Psi_{\mathrm{w}}^{\text {tlp }}\right|$ was positively correlated. The rootstock treatment rank of the comprehensive evaluated result (the $R_{3}$ value) from high to low was 'Peruque', 'VC1-68', 'Giles', 'Moore', 'Major', 'San Felipe', 'Frutoso', '87MX1-2.2', 'Elliott', '87MX5-1.7', 'Riverside', and 'Posey', respectively (Table 3 ). The osmotic regulating ability (Fig. 5C) also could be classified into four small categories: the higher group ('Peruque', 'VC1-68'), the relatively higher group ('Giles', 'Moore', 'Major'), the relatively lower group ('Frutoso', '87MX12.2', 'Elliott') and the lower group ('87MX51.7', 'Riverside', 'Posey').

The stomatal response sensitivity also was analyzed using the subordinate function method in the same manner as described previously. The negatively correlated parameters of the $D$ value, $\mathrm{T}_{\mathrm{S}}$, and $\mathrm{T}_{\mathrm{C}}$ were selected for calculation. The rootstock treatment rank of the comprehensive evaluated result (the $\mathrm{R}_{4}$ value) from high to low was 'Peruque', 'Giles', 'Riverside', 'VC1-68', '87MX12.2', 'Posey', 'Elliott', 'San Felipe', 'Moore', 'Frutoso', 'Major', and '87MX5-1.7', respectively (Table 3). Among them, the cluster analysis (Fig. 5D) indicated that the 'Peruque', 'Giles', and 'Riverside' treatments could be classified into the group that included the rootstock treatments with the 
Table 2. Effects of cutting shoot transpiration on several parameters in grafted 'Pawnee' tree shoots from different pecan seedling rootstocks

\begin{tabular}{|c|c|c|c|c|c|c|}
\hline Rootstock & Total leaflet area $\left(\mathrm{cm}^{2}\right)$ & Ts (h) & Tc (h) & $\operatorname{STR}\left(\mathrm{mmol} \cdot \mathrm{m}^{-2} \cdot \mathrm{s}^{-1}\right)$ & $\operatorname{CTR}\left(\mathrm{mmol} \cdot \mathrm{m}^{-2} \cdot \mathrm{s}^{-1}\right)$ & $D$ value $(\mathrm{mg})$ \\
\hline $87 \mathrm{MX} 1-2.2$ & $25.42 \mathrm{ab} \pm 2.44$ & $1.09 \mathrm{a} \pm 0.05$ & $8.67 \mathrm{bc} \pm 1.94$ & $0.77 \mathrm{a} \pm 0.16$ & $0.20 \mathrm{ab} \pm 0.05$ & $9.18 \mathrm{ab} \pm 2.25$ \\
\hline $87 \mathrm{MX} 5-1.7$ & $24.96 \mathrm{ab} \pm 4.26$ & $1.15 \mathrm{a} \pm 0.04$ & $13.49 \mathrm{a} \pm 6.39$ & $0.82 \mathrm{a} \pm 0.22$ & $0.20 \mathrm{ab} \pm 0.04$ & $9.14 \mathrm{ab} \pm 2.73$ \\
\hline Elliott & $26.91 \mathrm{ab} \pm 2.88$ & $1.11 \mathrm{a} \pm 0.04$ & $9.56 \mathrm{abc} \pm 2.72$ & $0.62 \mathrm{a} \pm 0.31$ & $0.17 b \pm 0.09$ & $8.96 \mathrm{ab} \pm 2.93$ \\
\hline Frutoso & $22.70 \mathrm{ab} \pm 1.57$ & $1.15 \mathrm{a} \pm 0.12$ & $10.58 \mathrm{abc} \pm 2.24$ & $0.97 \mathrm{a} \pm 0.30$ & $0.22 \mathrm{ab} \pm 0.06$ & $10.62 \mathrm{ab} \pm 2.40$ \\
\hline Giles & $24.62 \mathrm{ab} \pm 4.10$ & $1.07 \mathrm{a} \pm 0.04$ & $10.02 \mathrm{abc} \pm 2.83$ & $0.77 \mathrm{a} \pm 0.23$ & $0.21 \mathrm{ab} \pm 0.08$ & $10.61 \mathrm{ab} \pm 3.98$ \\
\hline Major & $24.60 \mathrm{ab} \pm 4.31$ & $1.16 \mathrm{a} \pm 0.06$ & $11.53 \mathrm{abc} \pm 1.88$ & $0.75 \mathrm{a} \pm 0.41$ & $0.19 \mathrm{ab} \pm 0.05$ & $10.51 \mathrm{ab} \pm 4.04$ \\
\hline Moore & $27.23 \mathrm{ab} \pm 3.90$ & $1.15 \mathrm{a} \pm 0.10$ & $10.50 \mathrm{abc} \pm 2.57$ & $0.92 \mathrm{a} \pm 0.41$ & $0.21 \mathrm{ab} \pm 0.07$ & $11.84 \mathrm{ab} \pm 4.26$ \\
\hline Peruque & $26.39 \mathrm{ab} \pm 5.67$ & $1.10 \mathrm{a} \pm 0.02$ & $7.89 \mathrm{bc} \pm 1.75$ & $0.84 \mathrm{a} \pm 0.36$ & $0.27 \mathrm{ab} \pm 0.16$ & $11.54 \mathrm{ab} \pm 6.39$ \\
\hline Posey & $28.91 \mathrm{a} \pm 2.75$ & $1.08 \mathrm{a} \pm 0.05$ & $7.65 \mathrm{bc} \pm 1.87$ & $1.05 \mathrm{a} \pm 0.35$ & $0.20 \mathrm{ab} \pm 0.08$ & $6.32 \mathrm{~b} \pm 1.99$ \\
\hline Riverside & $23.21 \mathrm{ab} \pm 2.98$ & $1.07 \mathrm{a} \pm 0.06$ & $7.28 \mathrm{c} \pm 2.15$ & $1.27 \mathrm{a} \pm 0.52$ & $0.26 \mathrm{ab} \pm 0.03$ & $6.51 \mathrm{ab} \pm 2.43$ \\
\hline San Felipe & $22.01 \mathrm{~b} \pm 3.77$ & $1.14 \mathrm{a} \pm 0.05$ & $12.24 \mathrm{ab} \pm 2.22$ & $1.24 \mathrm{a} \pm 1.02$ & $0.35 \mathrm{a} \pm 0.25$ & $12.76 \mathrm{a} \pm 5.65$ \\
\hline $\mathrm{VC} 1-68$ & $27.98 \mathrm{ab} \pm 5.36$ & $1.07 \mathrm{a} \pm 0.04$ & $7.95 \mathrm{bc} \pm 2.43$ & $0.95 \mathrm{a} \pm 0.61$ & $0.21 \mathrm{ab} \pm 0.04$ & $7.12 \mathrm{ab} \pm 3.66$ \\
\hline
\end{tabular}

The same lowercase letters indicate no significant difference $(P>0.05)$, whereas different lowercase letters indicate a significant difference $(P<0.05)$.

Table 3. Comparison of four comprehensive indices of different pecan seedling rootstock treatments.

\begin{tabular}{lcccc}
\hline Rootstock & $\mathrm{R}_{1}$ & $\mathrm{R}_{2}$ & $\mathrm{R}_{3}$ & $\mathrm{R}_{4}$ \\
\hline 87MX1-2.2 & 0.390 & 0.645 & 0.370 & 0.649 \\
87MX5-1.7 & 0.530 & 0.537 & 0.325 & 0.177 \\
Elliott & 0.435 & 0.822 & 0.348 & 0.548 \\
Frutoso & 0.271 & 0.380 & 0.394 & 0.423 \\
Giles & 0.300 & 0.622 & 0.617 & 0.742 \\
Major & 0.307 & 0.422 & 0.579 & 0.322 \\
Moore & 0.317 & 0.295 & 0.585 & 0.477 \\
Peruque & 0.619 & 0.384 & 0.667 & 0.792 \\
Posey & 0.783 & 0.701 & 0.296 & 0.610 \\
Riverside & 0.583 & 0.670 & 0.298 & 0.669 \\
San Felipe & 0.366 & 0.420 & 0.441 & 0.489 \\
VC1-68 & 0.501 & 0.626 & 0.652 & 0.663 \\
\hline R & &
\end{tabular}

$\mathrm{R}_{1}=$ comprehensive index of drought resistance; $\mathrm{R}_{2}=$ comprehensive index of water-saving ability; $\mathrm{R}_{3}=$ comprehensive index of osmosis modulation; $\mathrm{R}_{4}=$ comprehensive index of stomatal response sensitivity.

highest stomatal response sensitivity. In contrast, the 'Major' and '87MX5-1.7' rootstock treatments could be classified into the group of the lowest stomatal response sensitivity.

\section{Discussion}

The water relationship of plants is an important aspect of their existence $(\mathrm{Xu}$ et al., 2004). In nature, the ability of a particular plant to absorb water and retain water coexists, and it is also reflected by strong or weak adaption to the changes in drought status. Therefore, the PV curve and transpiration methods can be used to obtain several water parameters to evaluate the drought tolerance and water-saving ability of one plant species or cultivar. By these evaluation methods, the order of drought tolerance for these different pecan seedling rootstock treatments from high to low was as follows: 'Posey', 'Peruque', 'Riverside', '87MX5-1.7', 'VC1-68', 'Elliott', '87MX12.2', 'San Felipe', 'Moore', 'Major', 'Giles', and 'Frutoso'.

When under traditional water stress, one plant adjusted itself in two manners, including osmotic regulation and high tissue elasticity, to maintain its turgor pressure. The $\Psi_{\mathrm{w}}{ }^{\text {sat }}$ revealed that the highest water potential of the turgor pressure (the absolute value approximated the turgor pressure) and the $\Psi_{\mathrm{w}}^{\text {tlp }}$ also benefited the plant cells by main- taining the lowest water potential of the turgor pressure. The plant osmotic regulation was the primary driving force of the cell water absorption, and the adjustment of cell osmotic potential could be reflected in the changes of $\Psi_{\mathrm{w}}^{\text {sat }}$ and $\Psi_{\mathrm{w}}{ }^{\text {tlp }}$. Therefore, in the analysis of the osmotic regulating ability, $\Psi_{\mathrm{w}}{ }^{\text {sat }}, \Psi_{\mathrm{w}}{ }^{\text {tlp }}$, and $\left|\Psi_{\mathrm{w}}{ }^{\text {sat }}-\Psi_{\mathrm{w}}{ }^{\text {tlp }}\right|$ were selected as the indices that were related to the osmotic regulating ability. $\left|\Psi_{\mathrm{w}}^{\text {sat }}-\Psi_{\mathrm{w}}^{\text {tlp }}\right|$ was a particularly important indicator of plant drought resistance. In the test, the 'Peruque' treatment showed the highest $\left|\Psi_{\mathrm{w}}^{\text {sat }}-\Psi_{\mathrm{w}}^{\text {tlp }}\right|$ value, indicating that it was better able to absorb water using osmotic adjustment, which was consistent with the order of drought tolerance. In addition, $\Psi_{\mathrm{w}}^{\text {tlp }}$ and RWC ${ }^{\text {tlp }}$ were related parameters. $\Psi_{\mathrm{w}}{ }^{\text {tlp }}$ reflected the external pressure on the plant leaf cells when the turgor pressure was zero, and RWC ${ }^{\text {tlp }}$ was the relative water content of the cells preserved under the environmental pressure. In the experiment, $\left|\Psi_{\mathrm{w}}^{\text {tlp }} \mathrm{X} R \mathrm{RWC}^{\text {tlp }}\right|$, which replaced $\mathrm{RWC}^{\text {tlp }}$, was a better parameter to use to evaluate drought tolerance. 'Posey' and '87MX5-1.7', the two treatments with the highest $\mid \Psi_{\mathrm{w}}^{\text {tlp }} \mathrm{X}$ RWC ${ }^{\text {tlp }} \mid$ values, were also the ones with the greatest degree of drought tolerance. In addition, $\mathrm{V}_{\mathrm{a}} / \mathrm{V}_{\mathrm{p}}$ was an important parameter to judge the resistance of the plants to stress. The 'Frutoso' seedling rootstock treatment with the lowest $\mathrm{V}_{\mathrm{a}} / \mathrm{V}_{\mathrm{p}}$ also had the lowest degree of drought tolerance. The higher the value of the $\varepsilon^{\max }$ indicated that the treatment had the hardest and least elastic cell wall. In the PV technique test, the 'Peruque' treatment had the lowest $\varepsilon^{\max }$ value, which contributed to its improvement in its ability to resist drought.

In the shoot-cutting transpiration test, the relative water content of the cutting shoot tissue when the stomata completely closed reflected the water content of the plant when photosynthesis could not take place, which was the water content of the plant tissue without its growing ability. In the test, the relative water content of the stomata of the 'Frutoso' and 'Moore' treatments was significantly lower when completely closed than that of the other seedling rootstock treatments, indicating that they lost the most water. Measurements of the loss of the relative water content from when the stomata began to close to when the stomata had completely closed indicated that 'Moore' and 'San Felipe' showed the largest degree of loss. This result was consistent with the order of water-saving and retention ability that indicated that the rootstock treatments of 'Frutoso', 'Moore', and 'San Felipe' were poorly expressed. The results of the $T_{S}$ and STR indicated there was no significant difference in the various seedling rootstock treatments. In addition, the different seedling rootstock treatments displayed similar values for their Tc and CTR. Therefore, it was hypothesized that the treatments of the different rootstocks were less influenced by the 'Pawnee' scion in their transpiration rate, which merits an additional transpiration rate test of the photosynthesis study before it can be considered proven.

For the comprehensively compared result, the treatments 'Posey', 'Peruque', 'Riverside', and '87MX5-1.7' exhibited high drought resistance. In addition, the 'Posey' treatment was more drought tolerant than the 'Peruque' treatment and the 'Riverside' treatment, but 'Posey' was between 'Peruque' and 'Riverside' in the maximum water potential at both the saturation point and incipient plasmolysis. In addition, the close results of the 'Peruque' and '87MX5-1.7' treatments in drought resistance were on opposite aspects of the dendrograms on water-saving ability, osmosis modulation, and stomata response sensitivity. The conflicting results were based on the subordinate function method from the parameters of the two tests. The weight of the different parameters was for the additional study to complete the formula, and more relative parameters needed to be proven and added for the evaluation method. In addition, it was reported that the seedlings from the northern rootstocks of 'Giles', 'Peruque', and 'Major' had higher levels of root and stem water percentages than those from the southern ('87MX1-2.2', '87MX5-1.7') and eastern ('Curtis', 'Elliott', 'Moore') seedstocks (Grauke and Starr, 2014). It was hypothesized that cytosine methylation and rootstock-scion interaction both contribute to this difference (Liu et al., 2018; Mo et al., 2018). The selected seedlings from the different seedstocks influenced the upper scion expression. Therefore, for this project, future research should focus more on different rootstock comparisons to characterize their vegetative and reproductive growth, physiological differences, and rootstockscion interaction molecular mechanisms. 


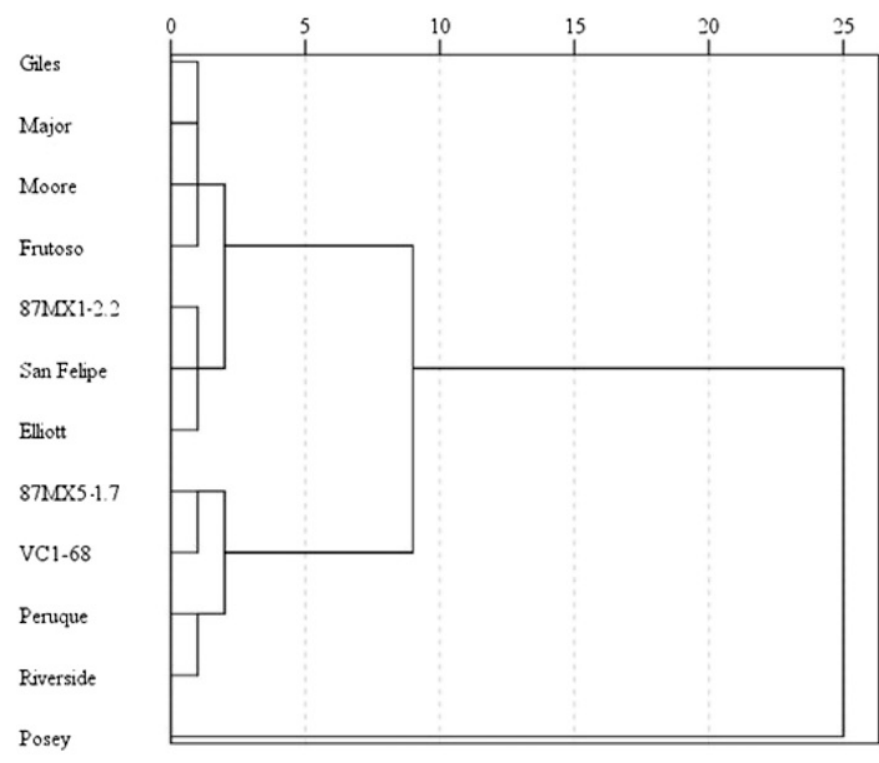

A

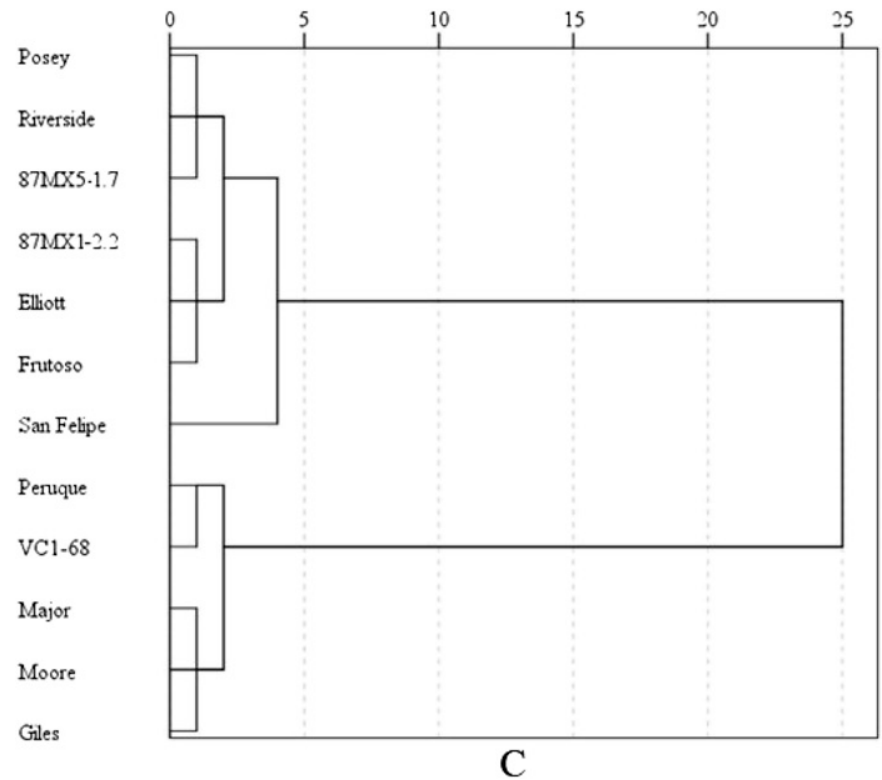

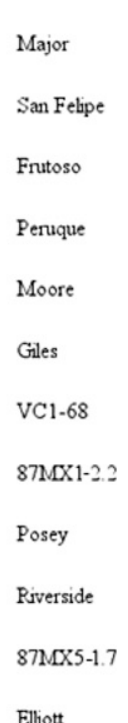

Elliott

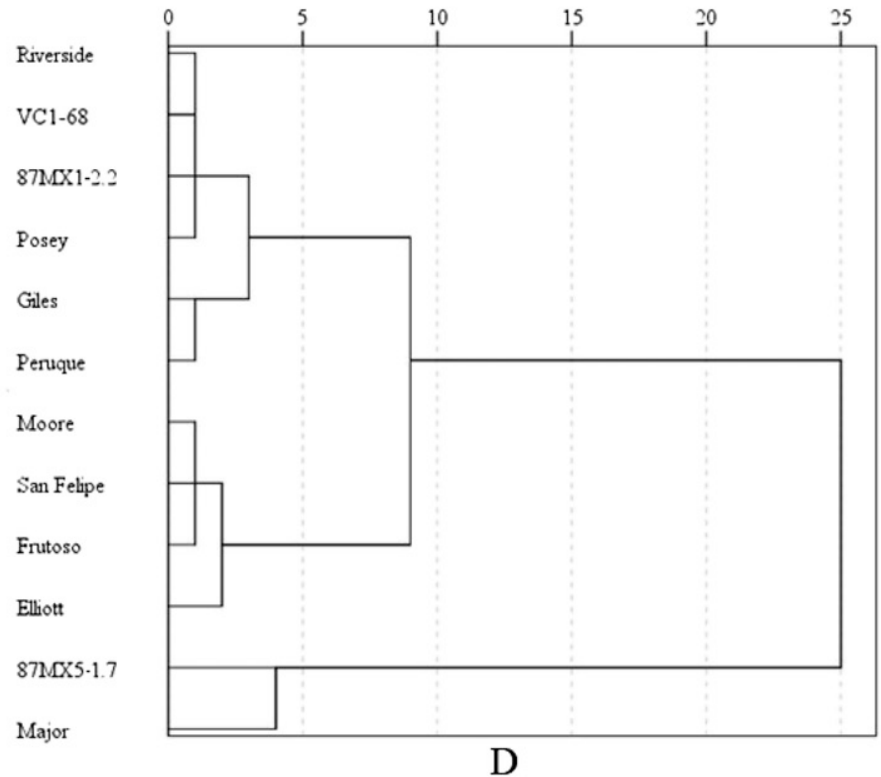

Fig. 5. Dendrogram trees of grafted 'Pawnee' trees from different pecan seedling rootstocks. (A) Dendrogram tree of drought resistance. (B) Dendrogram tree of water-saving ability. (C) Dendrogram tree of osmosis modulation. (D) Dendrogram tree of stomata response sensitivity.

However, there are many other pecan rootstock selection questions that still remain to be answered. For instance, regional adaptation is one significant aspect to be considered to develop improved methods of selection. Regional differences in soils and climates, coupled with long-term adaptation in native populations, reinforce the recognition of the regional boundaries of seed stock deployment. The resolution of rootstock effects will increase as other methods of evaluation are refined and used in critically structured test systems that control the variable of the seedling rootstock.

\section{Conclusions}

In conclusion, the different pecan seedling rootstock treatments influenced the grafted 'Pawnee' trees to varying degrees when the characteristics of drought resistance, water-saving ability, osmosis modulation, and stomata response sensitivity were examined. In addition, the order of drought tolerance for these different pecan seedling rootstock treatments from high to low was as follows: 'Posey', 'Peruque', 'Riverside', '87MX5-1.7', 'VC168', 'Elliott', '87MX1-2.2', 'San Felipe', 'Moore', 'Major', 'Giles', and 'Frutoso'.

\section{Literature Cited}

Carpenter, T., W. Neel, and P. Hedin. 1979. A review of host plant resistance of pecan, Carya illinoinensis, to Insecta and Acarina. Bull. Ecol. Soc. Amer. 25:251-257.

Casales, F.G., E. Van der Watt, and G.M. Coetzer. 2018. Propagation of pecan (Carya illinoinensis): A review. Afr. J. Biotechnol. 17:586-605.

Grauke, L. 2010. Pecan seed stock selectionregional implications. Proc. Southeastern Pecan Growers Assn. 103:42-51.
Grauke, L., M.A. Mendoza-Herrera, A.J. Miller, and B.W. Wood. 2011. Geographic patterns of genetic variation in native pecans. Tree Genet. Genomes 7:917-932.

Grauke, L. and R.D. O’Barr. 1996. Initial survival of pecan grafts on seedling rootstock of pecan, water hickory, and their interspecific hybrid. HortTechnology 6:45-48.

Grauke, L. and J. Pratt. 1992. Pecan bud growth and freeze damage are influenced by rootstock. J. Amer. Soc. Hort. Sci. 117:404-406.

Grauke, L. and J.L. Starr. 2014. Phenotypic screening of pecan seedling rootstocks in search of nematode resistance. Trees 28:1333-1341.

Guo, J., B. Wang, G.-B. Wang, Y.-Q. Wu, and F.-L. Cao. 2018a. Vertical and seasonal variations of soil carbon pools in ginkgo agroforestry systems in eastern China. Catena 171:450-459.

Guo, J., G.-B. Wang, Q.-Z. Geng, Y.-Q. Wu, and F.-L. Cao. 2018b. Decomposition of tree leaf litter and crop residues from ginkgo agroforestry 
systems in Eastern China: An in situ study. J. Soils Sediments 18:1424-1431.

Hammar, H.E. and J.H. Hunter. 1949. Influence of fertilizer treatment on the chemical composition of Moore pecan leaves during nut development. Plant Physiol. 24:16-30.

Huang, Y.-J., L.-H. Xiao, Z.-R. Zhang, R. Zhang, Z.-J. Wang, C.-Y. Huang, R. Huang, Y.-M. Luan, T.-Q. Fan, and J.-H. Wang. 2019. The genomes of pecan and Chinese hickory provide insights into Carya evolution and nut nutrition. Gigascience 8:36.

Lazarotto, M., P. Milanesi, M. Muniz, L. Reiniger, R. Beltrame, R. Harakava, and E. Blume. 2014. Morphological and molecular characterization of Fusarium spp pathogenic to pecan tree in Brazil. Genet. Mol. Res. 13:9390-9402.

Li, H.-J., X.-Y. Di, J.-W. Chen, and M.-B. Wang. 2004. A method of calculating osmotic water potential [ $\left.\psi \_(t l p)\right]$ at turgor loss point in PV curve. Bull. Bot. Res. 20:268-272.

Liu, Z.-Z., T. Chen, F.-R. Peng, Y.-W. Liang, P.-P. Tan, Z.-H. Mo, F. Cao, Y.-J. Shang, R. Zhang, and Y.-R. Li. 2018. Variation in cytosine methylation among pecan cultivars at different developmental stages. J. Amer. Soc. Hort. Sci. 143:173-183.

Mo, Z.-H., G. Feng, W.-C. Su, Z.-Z. Liu, and F.-R. Peng. 2018. Transcriptomic analysis provides insights into grafting union development in pecan (Carya illinoinensis). Genes (Basel) 9:71.

Scholander, P.F., E.D. Bradstreet, E. Hemmingsen, and H. Hammel. 1965. Sap pressure in vascular plants: Negative hydrostatic pressure can be measured in plants. Science 148:339-346.

Sitton, B. and F. Dodge. 1938. Growth and fruiting of three varieties of pecans on different seedling rootstocks. Proc. Amer. Soc. Hort. Sci. 38:121-125.

Tyree, M. and H. Hammel. 1972. The measurement of the turgor pressure and the water relations of plants by the pressure-bomb technique. J. Expt. Bot. 23:267-282.

Wakeling, L.T., R.L. Mason, B.R. D'Arc, and N.A. Caffin. 2001. Composition of pecan cultivars Wichita and western Schley [Carya illinoinensis (Wangenh.) K. Koch] grown in Australia. J. Agr. Food Chem. 49:1277-1281.

Wilson, J., M. Ludlow, M. Fisher, and E. Schulze. 1980. Adaption to water stress of the leaf water relation of four tropical species. Austral. J. Plant Physiol. 7:207-220.

Wood, B.W. 2001. Production unit trends and price characteristics within the US pecan industry. HortTechnology 11:110-118.

Wood, B.W., J.A. Payne, and L.J. Grauke. 1990. The rise of the US pecan industry. HortScience 25:594, 721-723.

Xu, H.-L., X.-J. Wang, J.-H. Wang, R.-Y. Xu, and U. Hiroshi. 2004. Leaf turgor potential, plant growth and photosynthesis in organically fertilized sweet corn. Pedosphere 14:1-7.

Xue, T.-T., J. Liu, Y.-B. Shen, and G.-Q. Liu. 2018. The microstructure of the suture in the pecan endocarp. J. Hort. Sci. Biotechnol. 93:441-448.

Zhang, J.-Y., Z.-R. Guo, R. Zhang, Y.-R. Li, L. Cao, Y.-W. Liang, and L.-B. Huang. 2015a. Auxin type, auxin concentration, and air and substrate temperature difference play key roles in the rooting of juvenile hardwood pecan cuttings. HortTechnology 25:209-213.

Zhang, R., F.-R. Peng, and Y.-R. Li. 2015b. Pecan production in China. Scientia Hort. 197:719727. 